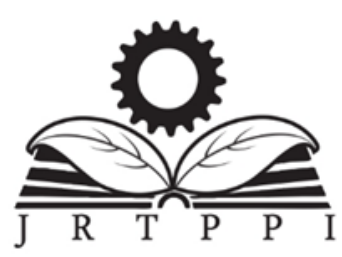

Vol. 11 No. 1 (2020) 1-11

Jurnal Riset

Teknologi Pencegahan Pencemaran Industri

Kementerian

Perindustrian

REPUBLIK INDONESIA

Journal homepage : http://www.jrtppi.id

\title{
Potential of Catalytic Ozonation in Treatment of Industrial Textile Wastewater in Indonesia
}

\author{
Rame Rame ${ }^{1,2, *}$, Purwanto Purwanto ${ }^{1,3}$, and Sudarno Sudarno ${ }^{1,4}$ \\ ${ }^{1}$ Doctorate Program in Environmental Science, School of Postgraduate Studies, Universitas Diponegoro, Semarang 50241, Indonesia \\ ${ }^{2}$ Center of Industrial Pollution Prevention Technology, Jl. Ki Mangunsarkoro No. 6, Semarang 50241, Indonesia \\ ${ }^{3}$ Department of Chemical Engineering, Faculty of Engineering, Universitas Diponegoro, Semarang 50275, Indonesia \\ ${ }^{4}$ Department of Environmental Engineering, Faculty of Engineering, Universitas Diponegoro, Semarang 50275, Indonesia
}

\section{A R T IC L E I N F O}

\section{Article history:}

Received 14 November 2019

Received in revised form 7 January 2020

Accepted 8 January 2020

Available online 21 May 2020

Keywords :

Textile wastewater

Catalytic treatment

Ozonation

Solid catalyst

\begin{abstract}
A B S T R A C T
Industrial textile wastewater is one of the most heavily polluting in Indonesia. Wastewater from industrial textile contains organic contamination that is very difficult to remove. The pollutants are remaining even though it has been treated by the conventional wastewater treatment and bio refractory in nature. Toxic organic compounds discharged from the textile industry, such as colored dyes, heavy metals, and various chemicals, will hurt the environment. These contaminants have been proven toxic to the biotic environment, such as mutagenic, which can increase the incidence of cancer and endocrine disruptor effects. Removal of contaminants from industrial textile wastewater is currently one of the most critical subjects in water pollution prevention. Applications of catalytic ozonation treatment initially, powder catalysts have been employed, and later, the use of activated carbon materials in more advanced catalyst structures reported, and more sophisticated types of catalyst equipment namely carbon nanotube, and nanoparticles. In-depth research on the combination of ozonation and catalytic research of industrial textile wastewater treatment has the potential to become a well-developed approach to treatment industrial textile wastewater. This review provides process principles and characteristics, including the use of various catalysts, variations in reactor design, and application catalytic ozonation in synthetic textile wastewater and real industrial textile wastewater outlined and discussed. Include future research directions of the treatment of industrial textile wastewater in to clean water with drink quality. This first time published review of the potential catalytic ozonation for the textile industry's wastewater treatment in Indonesia.
\end{abstract}

\section{INTRODUCTION}

The textile industry is a manufacturing sector that receives development priorities accordingly, "Making Indonesia 4.0" action plan. Some radical changes need to be adopted in the textile industry by optimizing the use of automation technology that can boost productivity and quality efficiently. The textile industry became a significant foreign exchange earner with export value reaching the highest compared to the previous year. Also, a million jobs have been contributed to by the textile industry. These make the textile industry requires relatively more labor and export-oriented sector. In a textile industry process, besides producing textile industry products, the impact of the process is to produce waste. The types of waste can be in the form of wastewater, exhaust emissions, and solid waste. From the industrial process to get 1 ton of product, it produces wastewater up to $100 \mathrm{~m}^{3}$. So that in one year, the industry with as many as 1 tons of textile industry products will donate wastewater up to $36,500 \mathrm{~m}^{3} /$ year. The estimated production capacity of textiles in Indonesia is 13 million tons in 2018. These are the main problem; namely,

\footnotetext{
${ }^{*}$ Correspondence author.

E-mail : rame@students.undip.ac.id (Rame)
}

doi : https://10.21771/jrtppi.2020.v11.no.1.p1-11

2503-5010/2087-0965@ 2018 Jurnal Riset Teknologi Pencegahan Pencemaran Industri-BBTPPI (JRTPPI-BBTPPI).

This is an open acces article under the CC BY-NC-SA license (https://creativecommons.org/licenses/by-nc-sa/4.0/).

Accreditation number : (LIPI) 756/Akred/P2MI-LIPI/08/2016 
the textile production process requires a very high quantity of water and massive discharge of wastewater at various stages of the coloring and finishing process.

The Indonesian textile industry's wastewater treatment technology in the early 1980s was conventional biological treatment. The basis for determining a wastewater treatment technology in the textile industry has not yet considered the factors of the availability of energy resources, sustainable water resources, and color parameters. It is because, at that time, there were no color quality standard requirements, Government still subsidized energy prices, and water resources were still abundant.

The determination of industrial wastewater treatment technology is entirely the policy of industry players or an awareness-based policy that meets the quality standard requirements. The first regulation was carried out by the Government by issuing Law Number 4 of 1982 concerning provisions of Principal Environmental Management. Law Number 5 of 1984 concerning Industry was continued. The Government does not have the authority to determine the type of wastewater treatment technology. However, the Government has regulatory authority in the requirements for achieving quality standards for industrial wastewater. The latest quality standards of industrial textile wastewater according to Indonesian Government regulations through ministerial regulations No. 16 of 2019 (Ministry of Environment and Forestry, 2019). The regulation contains the obligations of the textile industry to meet quality standards for wastewater, especially for color parameters. Because the textile industry is only concerned with profit alone without regard to the availability of natural resources, both water and air, and energy, is an inappropriate approach. Improvement of the environment through the prevention of water and air pollution will improve the welfare of the industry and society.

Precipitation and filtering is a physics-based wastewater treatment technology that is easily applied. The rough filtering using media such as sand, coral, and coconut shell charcoal, as well as palm fiber. However, precipitation and filtering are limited to coarse contamination and water- insoluble contamination. While dissolved contaminants in the water, there is still a lot in treated water. Furthermore, biological basis wastewater treatment technology was developed to overcome dissolved contamination. Conventional biological treatment processes applied to textile industry wastewater in Indonesia. The technology is useful for removing dyes that are not soluble in water (dye disperse). However, the price factor of the dye and ease of use cause the industry prefers to use dyes that are soluble in water (reactive dyes) so that biological wastewater treatment fail to meet the color quality standards according to regulations. Anaerobic bacteria cannot completely isolate the dye, causing unexpected reactions and toxic amine byproducts formed in wastewater (Robinson et al., 2002). Coloring metabolites can cause anaerobic reactor function instability. A probably similar phenomenon applies to water-insoluble dye. Most likely Anaerobic bacteria will find it difficult to break down water-insoluble dye.

Furthermore, the aromatic amine from the anaerobic degradation process dye is not fully converted to $\mathrm{CO}_{2}$ and $\mathrm{H}_{2} \mathrm{O}$ in an open reactor with a degradation process is assisted by air circulation. Often wastewater from the textile industry, which still contains color, is channeled directly into the environment without adequate handling, which leads to the emergence of water pollution that is very difficult to handle because it has entered the river or other water bodies. Colored wastes will increase the need for chemical oxygen (COD) from the aquatic environment and reduce the re-oxygenation process, thus affecting the development of photoautotrophic organisms. Dyestuff contamination will have an impact on the stunted development and growth of aquatic organisms and damage the natural ecosystem in aquatic life due to the difficulty of photosynthetic activity due to the low quantity of sunlight energy that can be absorbed by the aquatic environment and thus significantly disrupting aquatic ecosystems (Venkatamohan et al., 2002). Most of the dyes with the main components of azo can cause poisoning at particular concentrations, can encourage the risk of cancer, and cause undesirable changes at the genetic level (Pinheiro and Touraud, 2004). 


\section{CURRENT INDUSTRIAL TEXTILE WASTEWATER TREATMENT}

Textile industry wastewater in Indonesia is generally only treated by conventional methods. As a

Table 1. Comparison of different wastewater treatment technologies in the textile industry

\begin{tabular}{|c|c|c|c|}
\hline Technologies & Result & Limitation & Ref. \\
\hline $\begin{array}{l}\text { Conventional physical } \\
\text { method } \\
\text { - Coagulation, } \\
\text { flocculation, }\end{array}$ & $\begin{array}{l}\text { removal of coarse contamination and } \\
\text { water-insoluble contamination. } \\
\text { adequate in removing dyes } \\
\text { contaminants }\end{array}$ & $\begin{array}{l}\text { many contaminants dissolved in the water } \\
\text { remain } \\
\text { produces potentially toxic sludge. Costly and } \\
\text { not been able to remove some color }\end{array}$ & $\begin{array}{l}\text { (Buscio et al., 2015) } \\
\text { (Dotto et al., 2019) }\end{array}$ \\
\hline $\begin{array}{l}\text { Conventional } \\
\text { biological method }\end{array}$ & $\begin{array}{l}\text { Removal of biodegradable } \\
\text { contaminants. }\end{array}$ & $\begin{array}{l}\text { Only suitable for biodegradable } \\
\text { contaminants. } \\
\text { produce high deposition of sludge and not } \\
\text { enough in removing ammonia }\end{array}$ & $\begin{array}{l}\text { (Handayani et al., } \\
\text { 2018) }\end{array}$ \\
\hline $\begin{array}{l}\text { Advanced method } \\
\text { - Fenton }\end{array}$ & $\begin{array}{l}\text { sufficient for soluble and insoluble } \\
\text { colors, and there is no change in } \\
\text { volume }\end{array}$ & $\begin{array}{l}\text { problems in sludge disposal and is very } \\
\text { expensive }\end{array}$ & $\begin{array}{l}\text { (Su et al., 2011; } \\
\text { Sarajar et al., 2019; } \\
\text { Marlina et al., 2019) }\end{array}$ \\
\hline - Ozonation process & $\begin{array}{l}\text { removing azo dyes and no change in } \\
\text { volume. }\end{array}$ & $\begin{array}{l}\text { not suitable for dispersion / insoluble water } \\
\text { dyes, aromatic dye releases, and short ozone } \\
\text { half-lives }\end{array}$ & $\begin{array}{l}\text { (Robinson et al., } \\
\text { 2001) }\end{array}$ \\
\hline - Photocatalytic & $\begin{array}{l}\text { removing azo dyes and no change in } \\
\text { volume. }\end{array}$ & the length of reaction time & $\begin{array}{l}\text { (Syahroni and } \\
\text { Djarwanti, 2015) }\end{array}$ \\
\hline $\begin{array}{l}\text { A combination of } \\
\text { ozonation and } \\
\text { catalytic processes }\end{array}$ & $\begin{array}{l}\text { reduce synthetic compounds, organic } \\
\text { compounds, and colors in } \\
\text { wastewater. environmentally friendly }\end{array}$ & short ozone half-lives & $\begin{array}{l}\text { (Hassaan and Nemr, } \\
\text { 2017) }\end{array}$ \\
\hline
\end{tabular}

result, the water discharged into water bodies still contains relatively high levels of contamination. The conventional method is limited to the removal of coarse contamination and water-insoluble contamination. While many contaminants dissolved in the water remain. It also has the potential to produce intermediate toxic compounds. The contamination has the potential to pollute watersheds and coastal coasts. Even though residents still used river water as a source of water, irrigation, agriculture, and livestock.

Colored, smelly, and polluted rivers that look white foamy pollutants covering the surface of the river are the current conditions in some Indonesian rivers. The condition of the river is very concerning. The high level of river pollution is also due to the small flow of river water and the still tremendous burden of wastewater from industry and domestic activities. Several textile companies related to river pollution get administrative sanctions. However, this incident did not only occur in the Citarum River. The same pollution problems also occur in several other rivers such as the Cileungsi River, Cikeas

River, and Bekasi River. With this condition, joint improvement needs to overcome controlling water pollution from its source. Correctly, the technology modification applied in wastewater treatment plants in textile companies. The conventional biological method less suitable applied to wastewater treatment from the textile dyeing process due to the low quantity of biologically biodegradable contaminants (Jain et al., 2014). Chemical oxidation has preferred a method to treat textiles (Hu et al., 2016b).

The other most commonly used methods are the Fenton and the ozonation process. The Fenton process is 
sufficient for soluble and insoluble colors, and there is no change in volume, but sludge formed, which causes problems in sludge disposal and is very expensive. Ozonation is useful for removing azo dyes that are applied in gas conditions so that there is no change in volume. However, ozonation is not suitable for dispersion / insoluble water dyes, aromatic dye releases, and short ozone half-lives
(Robinson et al., 2001). Other studies using selected microorganisms that immobilized not enough in removing ammonia (Handayani et al., 2018). While the use of photocatalytic still has not shown satisfactory results because of the length of reaction time (Syahroni and Djarwanti, 2015).

Table 2. Comparison of removal contamination performances using the different catalyst

\begin{tabular}{|c|c|c|c|}
\hline Catalyst & Input textiles & Result & Ref. \\
\hline $\begin{array}{l}\mathrm{Fe}^{2+} \text { and zero valent iron } \\
\text { nanoparticles }\end{array}$ & $\begin{array}{l}\text { complex textile } \\
\text { effluent }\end{array}$ & $\begin{array}{l}\text { higher biodegradability index (BOD } 5 / \mathrm{COD}=\mathrm{BI}) \\
\text { enhancement up to } 0.61(134.6 \%) \text { along with } \mathrm{COD} \text {, } \\
\text { color and toxicity removal up to } 73.5 \%, 87 \% \text {, and } 92 \% \\
\text { respectively. }\end{array}$ & (Malik et al., 2018) \\
\hline alumina catalyst & $\begin{array}{l}\text { real industrial textile } \\
\text { WW }\end{array}$ & $\begin{array}{l}\text { Removal } 34.8 \% \text { of TOC, } 40.2 \% \text { of COD and } 75.1 \% \\
\text { blue dye }\end{array}$ & $\begin{array}{l}\text { (Polat, Balci, and } \\
\text { Özbelge, 2015) }\end{array}$ \\
\hline copper-doped zinc oxide & $\begin{array}{l}\text { real textile } \\
\text { wastewater }\end{array}$ & removes $89 \%$ of COD within 30 min of reaction & (Nakhate et al., 2019) \\
\hline $\begin{array}{l}\text { mesoporous carbon } \\
\text { aerogel supported cobalt } \\
\text { oxide nanoparticles }\end{array}$ & $\begin{array}{l}\text { the first spent dyeing } \\
\text { bath }\end{array}$ & $\begin{array}{l}99 \% \text { decolorization and COD reduction efficiency } \\
70 \% \text {. }\end{array}$ & (Hu et al., 2016a) \\
\hline $\begin{array}{l}\text { ceria-activated carbon } \\
\text { composite }\end{array}$ & $\begin{array}{l}\text { Synthetic textile } \\
\text { dyes }\end{array}$ & $\begin{array}{l}\text { mineralization degrees of } 100 \%, 98 \% \text {, and } 97 \% \text { after } \\
\text { two hours, respectively for CI Reactive Blue 5, CI Acid } \\
\text { Blue 113, and CI Reactive Yellow 3. }\end{array}$ & (Faria et al., 2009) \\
\hline $\begin{array}{l}\text { carbon aerogel supported } \\
\text { copper oxide }\end{array}$ & Textile dyeing WW & $\begin{array}{l}\text { COD removal could reach } 46 \% \text { in catalytic ozonation } \\
\text { system after } 60 \text {-min reaction }\end{array}$ & (Hu et al., 2016) \\
\hline $\begin{array}{l}\mathrm{C}-\mathrm{MgO} \text { doped on an } \\
\text { eggshell membrane } \\
\text { powder }\end{array}$ & $\begin{array}{l}\text { real textile } \\
\text { wastewater }\end{array}$ & $\begin{array}{l}\text { the degradation and mineralization were calculated to be } \\
93 \% \text { and } 78 \% \text {, respectively. }\end{array}$ & (Asgari et al., 2019) \\
\hline Perfluoro octyl alumina & $\begin{array}{l}\text { Textile wastewaters } \\
\text { (WWs) }\end{array}$ & $\begin{array}{l}98.37 \% \text { removal for Basic Yellow } 28 \text { and } 97.38 \% \\
\text { removals for Basic Red } 18.1\end{array}$ & (Polat et al., 2015) \\
\hline
\end{tabular}

Thus, the treatment of colored wastewater in the textile industry is a significant need at this time, so the development of new, innovative, and efficient and economical processing technologies are needed. Separation and reuse of treated water from the textile industry wastewater can be an additional advantage given the economic value of process water. The combination of ozonation and catalytic processes is one approach to environmentally friendly Advanced Oxidation Processes technologies (Duprez and Fabrizio, 2018; Gil et al., 2018). Catalytic ozonation can reduce synthetic compounds, organic compounds, and colors in wastewater (Wang et al., 2019). During catalytic ozonation, $\mathrm{O}_{3}$ molecules oxidize organic molecules through selective or non-selective radical reactions. $\mathrm{O}_{3}$ molecules also selectively attack unsaturated chromophore bonds through electrophilic or non-selective substitution through the formation of intermediate compounds in the form of hydroxyl radicals, generated in color loss continued by the degradation of other organic contaminants that are not biologically decomposed (Hassaan and Nemr, 2017). Several recent studies have shown that catalytic ozonation can increase the 
concentration of hydroxyl radicals to increase the mineralization of organic contamination (Ma et al., 2018).

\section{CATALYTIC OZONATION FOR INDUSTRIAL TEXTILE WASTEWATER}

Advanced oxidation processes (AOP) use different oxidations to turn most of the chemical contaminants in wastewater back into $\mathrm{CO}_{2}$ gas and water. The performance of the technology depends on the quantity of formation of a compound between hydroxyl radicals that will break down contaminants in wastewater into smaller compounds. The various AOP because of differences in energy, sources, and stages of formation: photochemical, photocatalysis, and chemical oxidation use of solid catalysts homogeneous or heterogeneous. The AOP approach is more useful for the removal of color contamination contained in wastewater from the textile industry because of a high rate of TOC removal and decolorization (Duprez and Fabrizio, 2018).

Increasing the number of intermediate compounds in the form of hydroxyl radicals and increasing the speed of decomposition are positive impacts of catalyst used (Ikhlaq et al. 2012). However, these methods should be adopted when other kinds of other simple technologies have not been able to provide the required degree of pollution removal. Some textile industry wastewater treatment uses Fenton but requiring $\mathrm{pH}$ conditioning and iron hydroxide sludge (Asghar et al., 2015).

Catalytic ozonation can reduce COD, color, and toxicity, and increase the biodegradability index $\left(\mathrm{BOD}_{5} /\right.$ $\mathrm{COD}=\mathrm{BI}$ ) in wastewater (Malik et al., 2018). Catalytic ozonation has proven to become the best potential choice for reuse of wastewater that is still in the textile industry for reuse. Catalytic ozonation has been proven to be able to process dyeing/dyeing wastewater into successive dyeing/coloring process water without reducing the color quality of the dyed fabric. The quality of treated water is better compared to the photocatalysis method, Fenton reaction, or ozonation alone. The reuse process will support environmental protection and the development of sustainability in the textile industry ( $\mathrm{Hu}$ et al., 2016a). Several research articles show an increase in the effectiveness and efficiency of the application of catalytic ozonation as an industrial wastewater treatment technology such as textiles (Asgari et al., 2019), pharmaceuticals (Chen and Wang, 2019), colors (Hu et al., 2016a), petrochemicals (Huang et al., 2019). Recent research shows catalytic ozonation with carbon nanotube (CNT) catalysts can increase the concentration of hydroxyl radicals 1000 times higher than in the water phase (Zhang et al., 2017) to increase the mineralization of organic contamination.

Several research articles show the efficiency of various types of material as a catalyst to improve catalytic processes. A comparison of removal contamination performances using different catalyst published in the literature is shown in Table 2. Various metal oxides such as magnesium oxide $(\mathrm{C}-\mathrm{MgO})$ carbon doped with carbon in powder (C-MgO-EMP) (Asgari et al., 2019)( $\mathrm{Fe}_{3} \mathrm{O}_{4} /$ $\mathrm{Co}_{3} \mathrm{O}_{4}$ (Chen and Wang, 2019), $\mathrm{Fe}_{2} \mathrm{O}_{3} / \mathrm{Al}_{2} \mathrm{O}_{3}$ (Rame et al., 2017), cobalt oxide nanoparticles (Hu et al., 2016b), carbon aerogel supported copper oxide (Hu et al., 2016a), iron-nickel (Huang et al., 2019) can be useful as a single component or combination of catalysts for the catalytic ozonation process in wastewater. Other research investigates the catalytic activity of graphical structures of carbon nanotubes (Zhang et al., 2017) and catalysts based on Fe shavings of industrial wastes ( $\mathrm{Li}$ et al., 2019) for catalytic ozonation in increasing hydroxyl radicals. However, the catalyst character has limited its application.

\subsection{Synthetic Textile Wastewater}

In this section, various catalysts, variations in reactor design for the ozonation catalytic in synthetic textile wastewater will be discussed. Single-bed reactors, reactors with continuous stirring, and fluidized have been applied in research studies for the removal of contaminants in the form of dyes and pigments that are still present in textile wastewater since they used as coloring agents. The increased oxidation rate results in the use of a catalyst in the form of copper sulfide powder in a single color removal in solutions such as Reactive Black, Remazol Brilliant Blue, or Red Acid (Pirgalioğlu and Özbelge, 2009).

Study of decomposition of oxamate, oxalate, and Reactive Blue (textile dyes) using catalytic ozonation with 
activated carbon, carbon xerogel, and cerium oxide catalysts and single ozonation control has developed demonstrate high-performance catalytic ozonation. The catalytic activity of the catalyst accrues with linear correlation with the quantity of activated carbon contained in activated carbon that is in contact with textile wastewater during the mineralization process (Orge et al., 2011). Approach to improving catalytic ozonation performance has been carried out with a more straightforward and more effective method of using polyacrylonitrile textile fibers (Gonçalves et al., 2015).

The optimum condition catalytic ozonation using mesoporous type bimetal catalyst with $\mathrm{Ru}-\mathrm{Cu} / \mathrm{SBA}-15$ component obtained dose $5000 \mathrm{mg} / \mathrm{m}^{3}$ and $\mathrm{pH}$ value 9 in artificial wastewater with reactive orange azo dye contamination, which results in the percentage of efficiency of color removal of $70.4 \%$ after the catalytic reaction for 1 hour. However, ideal catalytic ozonation will not be obtained if bicarbonate ions are present in textile wastewater because these ions act as inhibitors of hydroxyl radical formation, which decrease the COD removal efficiency significantly from $90 \%$ to $30.2 \%$ after four hours of catalytic ozonation (Ghuge and Saroha, 2018). Catalytic ozonation process obtained Reactive Black 5 removal efficiency of $54.03 \%$ using a bone-char (BC) ash decorated with $\mathrm{MgO}-\mathrm{FeNO}_{3}$. The optimal values for $\mathrm{pH}$, dyes concentration, reaction time, and catalyst quantity, and were determined $10,10 \mathrm{mg} / \mathrm{L}, 15 \mathrm{~min}$, and $100 \mathrm{mg} / \mathrm{L}$, respectively (Asgari et al., 2017).

\subsection{Real Industrial Textile Wastewater}

In this section, application catalytic ozonation in real industrial textile wastewater will be discussed, including their advantages and disadvantages, and include the use of various catalysts, variations in reactor design, and scale application. Pilot-scale catalytic ozonation of wastewater obtained from processes in the textile industry that was tested on a pilot scale use of copper-doped zinc oxide as catalysts already implemented. The $1000 \mathrm{mg} / \mathrm{L} \mathrm{Cu}$-doped $\mathrm{ZnO}$ by regulating ozone flow of $4000 \mathrm{mg} / \mathrm{m}^{3}$ and $\mathrm{pH} 7.2$ for 30 minutes the catalytic reaction was able to eliminate $89 \%$ COD. Reduction of COD by catalytic ozonation increased performance in sixfold compared with single ozonation. The catalytic ozonation is resulting in savings in energy consumption during the process of three folds more energy-efficient than that of single ozonation. Wastewater treatment uses an approach catalytic ozonation is a promising wastewater treatment solutions that are more efficient and effective compared to treatment technologies that have been widely installed in the textile industry (Nakhate et al., 2019).

However, much research on catalytic ozonation has a goal in removing single contaminants or specific azo dyes, but several studies have carried out treatment of wastewater taken directly from the textile industry. Research of catalytic ozonation of wastewater obtained from finishing and dyeing to follow by biological activated carbon has been done. The cost of applying catalytic ozonation with $\mathrm{O}_{3} / \mathrm{rGAC}-\mathrm{BAC}$ is USD 6 for $100 \mathrm{~m}^{3}$ of textile industry wastewater for removal COD $71 \%$ and $43 \%$ of those for $\mathrm{O}_{3} / \mathrm{rGAC}$ alone and $\mathrm{BAC}$ alone, respectively (Wang et al., 2019). While the efficiency of catalytic ozonation with C-MgO-EMP catalyst for textile industry liquid waste based on color and TOC parameters is to be $93 \%$ and $78 \%$, respectively (Asgari et al., 2019). The results of other studies indicate there are still around 214 species of organic pollutants that are still detected from treated water in the biological treatment unit of the wastewater finishing process of the textile industry. However, after the biologically treated water is treated with ozonation catalytic, it is obtained a decrease into 34 harmless species (Wu et al., 2016).

Based on the COD parameters, one of the studies has successfully used catalytic ozonation in the treatment of real industrial textile wastewater. Research using a reactor that is divided into three containers is different from the alumina catalyst. The reactor is a fluidized cylindrical column with a height dimension of $100 \mathrm{~cm}$ and a radius of $4 \mathrm{~cm}$. COD and dye degradation showed that alkaline $\mathrm{pH}$ degradation is more optimal when using alumina catalysts. The efficiency of catalytic ozonation depended much on the surface catalyst, characteristics of dyes, and $\mathrm{pH}$ of the solution (Polat et al., 2015). 


\section{FUTURE RESEARCH DIRECTIONS}

From several results of catalytic ozonation research in textile wastewater, it turns out that the method is still not able to destroy the entire contamination. So that further processing is still needed to maximize the removal of the remaining contaminants. The treatment of industrial textile wastewater always faces limitations when using the current processing stage. An alternative breakthrough for these problems includes the approach to the right combination of advanced oxidation processes includes filtration. However, much current research has focused on the various catalyst, reactor catalytic process, and various input textiles. While the future tendency to optimize automatic analysis, with the sensor for controlling the whole treatment process. Also, process optimization, low energy consumption, and simple operational mechanism are commonly carried out in automatic catalytic reactors, which will be the best solution for industrial textile wastewater treatment.

Very little research conducted concentrating catalytic ozonation performance tests to find out whether it is included in the category of efficient and effective technology for treating textile wastewater for modem wastewater reuse. Future research needs to find the right and optimum technology for sustainable development of the textile industry and cleaner production of textile dyeing $(\mathrm{Hu}$ et al., 2016a). Also the analysis of ecological trails needs to be done to determine the capacity and durability of pollution loads (Budihardjo et al., 2013). In addition to the operator WWT has competence in knowing the characteristics of waste water including color, smell, and taste, fish can be utilized for biocentration as well as biomonitoring of wastewater treatment processes (Hidayah et al., 2014).

The application of WWT catalytic ozonation bases is still tricky in Indonesia. Research on catalytic ozonation prototypes with a combination of Aluminum and Iron base catalysts has succeeded in treating the textile industry wastewater (Rame et al., 2017). Nevertheless, the industry is still reluctant to implement catalytic ozonation technology. Some industries are still hesitant to build WWT catalytic ozonation because there are no concrete examples of WWT in the Indonesian industry. At present, the application of the industry is limited to ozonation combined with anaerobes and aerobes. The industry might be interested if WWT catalytic ozonation output can be reused as production process water, clean water, and drinking water.

Besides, the industry is still worried about WWT catalytic ozonation operational costs, which are considered very expensive in its investment. Research on the development of new renewable energy utilization in WWT catalytic ozonation operations will undoubtedly provide more significant benefits. Like solar cell energy and biomass. Instrumentation and automation based wireless sensors can be used as a quality monitoring system for waste water to lower the operational costs of treatment and electrical energy (Purwanto et al., 2019). The operational costs of WWT will not burden the industry. The operational cost has been a common obstacle for the construction of WWT industries.

The capacity and quality of the textile industry wastewater are very diverse. Because of the many types of textile production stages, there is almost no textile wastewater that has the same characteristics. Therefore, future research will focus on wastewater treatment technology that can automatically identify the quality and quantity of contaminants in wastewater as well as full control of the wastewater treatment system. So that later wastewater treatment plants with this technology can be applied to all types of textile industries.

The installation of monitoring units in realtime and online in treated water will become an industry requirement in the future. These are to ensure that the textile industry commits treating wastewater into clean water that will not pollute the surrounding environment. A more accessible, cheaper, and faster process approach while still considering the impact and benefits on the environment will also be the focus of future research in the textile industry wastewater management. So far, research is still limited to treating the textile industry wastewater into quality water for irrigation, washing water, and meeting plant needs. Research with output in the form of clean water with quality as drinking 
water, raw material water, and industrial production process water will be an exciting challenge for future research.

\section{CONCLUSION}

The practical and efficient application of wastewater treatment technology in the textile industry needs to be realized immediately to prevent the potential for environmental pollution due to installing technology that is still not optimal in destroying pollution. Awareness about conventional wastewater treatment that still passes pollution into the environment needs to socialized to the textile industry and the community. These are to prevent dangerous risks to public health and the environment due to exposure to pollution. Research on catalytic ozonation in synthetic textile wastewater and real industrial textile wastewater shows the potential for catalytic ozonation. This likely an alternative in removing contaminants from the textile industry wastewater. Research on the utilization of renewable energy in WWT catalytic ozonation for reuse textile wastewater today is one of the most critical subjects in preventing water pollution. The treatment of textile industry wastewater into clean water and drinking water using catalytic ozonation has the opportunity to improve processing performance so that it is faster, cheaper, and more sustainable.

\section{ACKNOWLEDGMENT}

The author thanks the Ministry Industry through Industrial Research and Development Agency for funding under DIPA Programme (2017).

\section{REFERENCE}

Asgari, G., Somaye A., Abdol M.S.M., Ali P., and Bahman R. 2017. "Preparation and Catalytic Activity of Bone-Char Ash Decorated with $\mathrm{MgO}$ - FeNO3 for Ozonation of Reactive Black 5 Dye from Aqueous Solution: Taguchi Optimization Data." Data in Brief 13: 132-36. https://doi.org/10.1016/j.dib.2017. 05.025.

Asgari, G., Javad F., Hassan Z.N., and Hamied E. 2019.
"Catalytic Ozonation of Industrial Textile Wastewater Using Modified C-Doped $\mathrm{MgO}$ Eggshell Membrane Powder." Advanced Powder Technology 30 (7): 1297-1311. https://doi.org/ 10.1016/j.apt.2019.04.003.

Asghar, ., Abdul A. A. R., and Wan M.A.W.D. 2015. "Advanced Oxidation Processes for In-Situ Production of Hydrogen Peroxide/Hydroxyl Radical for Textile Wastewater Treatment: A Review." Journal of Cleaner Production 87 (1): 826-38. https://doi.org/10.1016/j.jclepro.2014. 09.010 .

Budihardjo, S.,Hadi S.P., Sutikno, S., Purwanto, P. 2013. "The ecological footprint analysis for assessing carrying capacity of industrial zone in Semarang." Scientific Research Publishing.

Buscio, V., Marín, M. J., Crespi, M, and Gutiérrez-Bouzán, C. 2015. "Reuse of Textile Wastewater after Homogenization-Decantation Treatment Coupled to PVDF Ultrafiltration Membranes." Chemical Engineering Journal 265 (1): 122-28. https://doi.org/10.1016/j.cej.2014.12.057.

Chen, H., and Jianlong W. 2019. "Catalytic Ozonation of Sulfamethoxazole over $\mathrm{Fe} 3 \mathrm{O} 4 / \quad \mathrm{Co} 3 \mathrm{O} 4$ Composites." Chemosphere 234: 14-24. https:// doi.org/10.1016/j.chemosphere.2019.06.014.

Dotto, J., Márcia R.F.K, Márcia T.V., Soraya M.P., and Rosangela B. 2019. "Performance of Different Coagulants in the Coagulation/Flocculation Process of Textile Wastewater." Journal of Cleaner Production 208:656-65. https://doi.org/ 10.1016/j.jclepro.2018.10.112.

Duprez, D., and Fabrizio, C. 2018. Handbook of Advanced Methods and Processes in Oxidation Catalysis.

Faria, P. C.C., Órfăo, J. J.M. and Pereira, M. F.R. 2009. "Activated Carbon and Ceria Catalysts Applied to the Catalytic Ozonation of Dyes and Textile Effluents." Applied Catalysis B: Environmental 88 (3-4): $\quad 341-50 . \quad$ https://doi.org/10.1016/ j.apcatb.2008.11.002.

Ghuge, S.P., and Anil K.S. 2018. "Catalytic Ozonation of 
Dye Industry Effluent Using Mesoporous Bimetallic Ru-Cu/SBA-15 Catalyst." Process Safety and Environmental Protection 118: 125-32. https://doi.org/10.1016/j.psep.2018.06.033.

Gil, A., Galeano, L. A. and Vincente, M. A. 2018. Applications of Advanced Oxidation Processes (AOPs) in Drinking Water Treatment.

Gonçalves, A.G., Jéssica M., Juliana P.S.S., José L. F., Manuel F.R.P., and José J.M.Ó. 2015. "Carbonized Polyacrylonitrile Fibers for the Catalytic Ozonation of Oxalic Acid." Catalysis Today 249: 59-62. https://doi.org/10.1016/ j.cattod.2014.12.045.

Handayani, Setianingsih, N.I. and M. Moenir. 2018. "Performance Of Immobilized-Selected Microorganisms In The Biodegradation Of Textile Industry Waste Wate." Jurnal Riset Teknologi Pencegahan Pencemaran Industri 9 (1): 29-37. https://doi.org/https://doi.org/ 10.21771/jrtppi.2018.v9.no1.p29-37.

Hassaan, M.A., and Ahmed E. 2017. "Advanced Oxidation Processes for Textile Wastewater Treatment." International Journal of Photochemistry and Photobiology 2 (3): 85-93.

Hidayah, A.M., Purwanto, P., Soeprobowati, T.R. 2014. "Biokonsentrasi faktor logam berat $\mathrm{Pb}, \mathrm{Cd}, \mathrm{Cr}$ dan Cu pada ikan nila (Oreochromis niloticus Linn.) di karamba Danau Rawa Pening." Bioma: Berkala Ilmiah Biologi 16 (1), 1-9

Hu, E., Xinbo W., Songmin S., Xiao M.T., Shou X.J., and Lu G. 2016a. "Catalytic Ozonation of Simulated Textile Dyeing Wastewater Using Mesoporous Carbon Aerogel Supported Copper Oxide Catalyst." Journal of Cleaner Production 112: 4710-18. https://doi.org/10.1016/j.jclepro.2015. 06.127.

Hu, S. S., Ming T. X., S. J., and Chiu, K. 2016 b. "Regeneration and Reuse of Highly Polluting Textile Dyeing Effluents through Catalytic Ozonation with Carbon Aerogel Catalysts." Journal of Cleaner Production 137: 1055-1065. https://doi.org/https://doi.org/10.1016/j.jclepro.2 016.07.194.

Huang, Y., Mengyu L., Zhihua X., Daofang Z., and Liang L. 2019. "Catalytic Ozonation of Organic Contaminants in Petrochemical Wastewater with Iron-Nickel Foam as Catalyst." Separation and Purification Technology 211 (May 2018): 269-78. https://doi.org/10.1016/j.seppur.2018.09.080.

Ikhlaq, A., David R. B., and Barbara K. 2012. "Mechanisms of Catalytic Ozonation on Alumina and Zeolites in Water: Formation of Hydroxyl Radicals." Applied Catalysis B: Environmental 123-124: 94-106. https://doi.org/10.1016/ j.apcatb.2012.04.015.

Jain, R.M., Kalpana H.M., Jitendra K., and Bhavanath J. 2014. "Biological Neutralization and Biosorption of Dyes of Alkaline Textile Industry Wastewater." Marine Pollution Bulletin 84 (1-2): 83-89. https://doi.org/10.1016/j.marpolbul.2014. 05.033 .

Li, X., Weiyu C., Luming M., Yuanxing H., and Hongwu W. 2019. "Characteristics and Mechanisms of Catalytic Ozonation with Fe-Shaving-Based Catalyst in Industrial Wastewater Advanced Treatment." Journal of Cleaner Production 222: 174-81. https://doi.org/10.1016/j.jclepro.2019. 03.084 .

Ma, J., Yunlu, C., Jianxin, N., Luming, M. , Yuanxing, H., Liang, L. and Yan, L. 2018. "Pilot-Scale Study on Catalytic Ozonation of Bio-Treated Dyeing and Finishing Wastewater Using Recycled Waste Iron Shavings as a Catalyst." Scientific Reports, 1-11.

Malik, S.N., Prakash C.G., Atul N.V., and Sandeep N.M. 2018. "Catalytic Ozone Pretreatment of Complex Textile Effluent Using $\mathrm{Fe}^{2+}$ and Zero Valent Iron Nanoparticles." Journal of Hazardous Materials 357 (May): 363-75. https://doi.org/10.1016/ j.jhazmat.2018.05.070.

Marlina, E., Purwanto, 2019. "Electro-Fenton for Industrial Wastewater Treatment: A Review." E3S Web Conf. 125, 1-5. https://doi.org/10.1051/ e3sconf/201912503003 
Ministry of Environment and Forestry. 2019. "Regulation of the Minister of Environment and Forestry of the Republic of Indonesia Number p.16/ Menlhk/Setjen/Kum.1/4/2019 Concerning the Second Amendment to the Regulation of the Minister of Environment Number 5 the Year 2014 About Wastewater Quality Sta."

Nakhate, P.H., Chandrakanth R.G., Nandkumar T.J., and Kumudini V.M. 2019. "Engineering Aspects of Catalytic Ozonation for Purification of Real Textile Industry Wastewater at the Pilot Scale.” Journal of Industrial and Engineering Chemistry 69: 77-89. https://doi.org/10.1016/j.jiec.2018. 09.010.

Orge, C. A., Órfăo, J.J.M. and Pereira, M. F.R. 2011. "Catalytic Ozonation of Organic Pollutants in the Presence of Cerium Oxide-Carbon Composites." Applied Catalysis B: Environmental 102 (3-4): 539-46. https://doi.org/10.1016/j.apcatb.2010. 12.036 .

Pinheiro, H. M, and Touraud, E. T. O. 2004. "Aromatic Amines from Azo Dye Reduction: Status Review with Emphasis on Direct UV Spectrophotometric Detection in Textile Industry Wastewaters." Dyes Pigm 61: 121-139.

Pirgalioğlu, S., and Tülay A.O. 2009. "Comparison of Non-Catalytic and Catalytic Ozonation Processes Robinson, T, Chandran, B. Naidu, S. and Nigam, P 2002. "Studies on the Removal of Dyes from Synthetic Textile Effluent Using Barley Husk in Static-Batch Mode and a Continuous Flow, Packed-Bed Reactor." Biores Technol 85: 43-49.

Sarajar, A.E.E., Ramadhania, R.P., Purwanto, P., 2018. "Organic pollutant degradation of tapioca flour industrial waste with photo-fenton reaction." MATEC Web Conf. 156, 1-4. https:// doi.org/10.1051/matecconf/201815603048.

Su, C., Massakul P., Chavalit R., and Ming Chun L. 2011. "Effect of Operating Parameters on the Decolorization and Oxidation of Textile Wastewater by the Fluidized-Bed Fenton Process." Separation and Purification Technology 83 (1): of Three Different Aqueous Single Dye Solutions with Respect to Powder Copper Sulfide Catalyst." Applied Catalysis A: General 363 (1-2): 157-63. https://doi.org/10.1016/j.apcata. 2009.05.011.

Polat, D., Irem B., and Tülay A.O. 2015. "Catalytic Ozonation of an Industrial Textile Wastewater in a Heterogeneous Continuous Reactor." Journal of Environmental Chemical Engineering 3 (3): 186071. https://doi.org/10.1016/j.jece.2015.04. 020.

Purwanto, P., Suryono, S., Sunarno, S., 2019. "Design of Air Quality Monitoring System Based on Web Using Wireless Sensor Network." J. Phys. Conf. Ser. 1295. https://doi.org/10.1088/1742-6596/ $1295 / 1 / 012043$

Rame, Agus P., and Agung B. 2017. "Treatment of Textile Waste Water Based Catalytic Ozonation With Iron (III) Oxide $\left(\mathrm{Fe}_{2} \mathrm{O}_{3}\right)$ and Aluminum Oxide $\left(\mathrm{Al}_{2} \mathrm{O}_{3}\right)$ Catalysts Using Micro Diffuser." Research Journal of Industrial Pollution Prevention Technology. https://doi.org/http:// dx.doi.org/10.21771/jrtppi.2017.v8.no2.p67-75.

Robinson, M.G., Marchant R., and Nigam P. 2001. "Remediation of Dyes in Textile Effluent: A Critical Review on Current Treatment Technologies with a Proposed Alternative." Biores Technol 77: 247-255.

100-105. https://doi.org/ 10.1016/j.seppur.2011.09.021.

Syahroni, C., and Djarwanti D. 2015. "Pengembangan Reaktor Fotokatalitik Rotating Drum Untuk Pengolahan Air Limbah Industri Tekstil.” Jurnal Riset Teknologi Pencegahan Pencemaran Industri 6 (2): $35 . \quad$ https://doi.org/10.21771/ vol6no2tahun2015artikel1238.

Venkatamohan, S, Rao, N. and Karthikeyan, J. 2002. "Adsorptive Removal of Direct Azo Dye from Aqueous Phase onto Coal-Based Sorbents: A Kinetic and Mechanistic Study.” J Hazard Mater B90: 189-204.

Wang, Z. H., Feifei, X.W., Xingaoyuan, T., Kun, Yubo, S. and Tingting, Y. 2019. "Application of 
Heterogeneous Catalytic Ozonation for Refractory Organics in Wastewater." Catalysts 9, (241).

Wang, W.L., Hong Y.H., Xin L., Hui X.S., Tian H.Z., Chun W., Zheng Y.H., and Qian Y.W. 2019. "Combination of Catalytic Ozonation by Regenerated Granular Activated Carbon (RGAC) and Biological Activated Carbon in the Advanced Treatment of Textile Wastewater for Reclamation.”
Chemosphere

231:

$369-77$.

https://doi.org/10.1016/j.chemosphere.2019.05.1 75.

Zhang, S., Xie Q., Jian F.Z., and Dong W. 2017. "Probing the Interphase 'HO[Rad] Zone' Originated by Carbon Nanotube during Catalytic Ozonation." Water Research 122: 86-95. https://doi.org/ 10.1016/j.watres.2017.05.063. 